\title{
The Effect of Boiling on Stability of Oxytetracycline and Sulfamethazine Residues in Raw Milk using HPLC Method
}

\author{
Fathy H., El-Toukhy ${ }^{2}$ M.E., Sabery ${ }^{1}$ M. El-Sherbiny ${ }^{2} M$. \\ ${ }^{1}$ Animal Health Research Institute, Department of Biochemistry, Toxicology and Feed Deficiency \\ ${ }^{2}$ Mansoura University, Department of Food Control and Hygiene
}

\section{ABSTRACT}

\begin{abstract}
Two hundred raw milk samples ( $250 \mathrm{ml}$ of each) were collected from small dairy farms, street peddlers and dairy shops in Mansoura Governorate. These samples were screened using Bacillus Subtilis Diffusion Assay for qualitative detection of antibiotics residues; where the percentage of suspected positive samples was 12.5\%. High Performance Liquid Chromatography - Ultra Violet detector (HPLC- UV) method was developed and validated to determine the amount of oxytetracycline (OTC) and sulfamethazine (SMZ) residues in raw milk before and after boiling. The results revealed that $8.5 \%$ of the raw milk samples were containing (OTC) residues (6.5\% of them exceed MRL) while, (SMZ) was detected in $4 \%$ of the raw milk samples ( $3 \%$ of them exceed MRL). Upon applying heat treatment, the reduction in the (OTC) content in milk boiled for 2 minutes was $30.5 \%$ but boiling for 5 minutes was accompanied with $54.1 \%$ reduction. On the other hand, the percentage of (SMZ) reduction was $1.7 \%$ and $9.5 \%$ in milk boiled for 2 and 5 minutes respectively which could be attributed to the low heat stability of (OTC) and high stability of (SMZ).
\end{abstract}

Keywords: (OTC), (SMZ), (HPLC- UV), Heat treatment.

\section{INTRODUCTION}

The popularity of raw and natural food is increasing. Raw milk and small- scale dairy products as cheeses are available directly from producers at home. These products have microbiological and chemical adverse effect on the consumer's health, as they could be contaminated with chemicals as: hygienic, agricultural, veterinary and environmental procedures (Claeyset al 2013, Khaniki 2007).Veterinary drugs are widely used in pharmaceutical manufacturing field; as a treatment, or for prophylaxis of animal diseases and also to enhance animal growth. Yet they have a major drawback represented in antibiotic residues. This problem results from the bad prolonged usage and the ignorance of drugs withdrawal periods which leads to the appearance of their residues not only in animal tissues, but also in animal byproducts as milk (Botsoglou and Fletouris 2001). Exceeding the levels of antimicrobial residues in milk has a deep impact on public health (Heeschen, 1993), where the possible common health risks are antibiotic resistance prescribed for human cure, abnormality in the gut microflora and sensitive reactions (Mitchell et al., 1998). While for the economic stand point, antibiotic residues have a negative effect on the starters used in fermentation process needed for cheese and yoghurt manufacture (Tamime and Robinson, 2007).

(OTC) is considered one of the oldest antibiotics that used routinely in the veterinary practice because of broad spectral activity and its multiple routes of administration. By the end of metabolism, $25-75 \%$ of the applied (OTC) are descended into bovine milk. Also, via the entero-hepatic circulation, a small amount of the applied dose may stay in the body for a long period (Botsoglou and Fletouris, 2001). So, if improper a pplication of antibiotic or the withdrawal time not elapsed (OTC) and their metabolites may be found in milk and evoke adverse effects on consumers (Fritz and Zuo, 2007). Sulfonamides are synthetic bacteriostatic compounds which used to cure infections and to improve feed efficiency. Many investigators reported their existence and residues in milk (Brady and Katz, 1988, Charm et al., 1988 and CollinsThompason et al., 1988), (SMZ) is considered to be the most carcinogenic member of this group and that is the reason for pushing the codex committee of FAO/WHO through limiting its maximum residue level (MRL) of $25 \mathrm{ppb}$ in milk (WHO, 1989 ), while in the EC the sulfonamides MRL in milk fixed at $100 \mathrm{ppb}$ (EEC, 1992).

In food safety programs, it is vital to monitor the veterinary drugs residues in raw animal products like milk, eggs and meat to keep public health (Botsoglou and Fletouris 2001and FAO, 2015). Recently, for residue analysis HPLC is used, its important increased day by day, many mobile phases, library of column packing and the variations in the process methods made its importance (Nollet, 1992).Boiling of milk is the most common method of heat treatment specially at home before consumption or processing to decrease the percent of zoonotic pathogens and to increase its validity period (Claeyset al 2013). The stability of antibacterial drugs was studied earlier (Moats 1999). So, from the last on-going 
two points, this present study seeks the quantitative determination of (OTC) and (SMZ) residues in raw milk samples using HPLC and to focus the light on the effect of boiling process on their residues in raw milk.

\section{MATERIALS AND METHODS}

\subsection{Milk samples}

Two hundred raw milk samples (250 $\mathrm{ml}$ of each) were collected from small dairy farms, street peddlers and dairy shops in Mansoura Governorate. These samples were received in clean dry sterile sampling bottles and placed in an ice box $\left(4^{\circ} \mathrm{c}\right)$ to be sent to the laboratory of Animal Health Research Institute, Dokki, Giza, for the detection of antibiotic residues in comparing with blank milk samples from untreated healthy cows.

\subsection{Preparation of milk samples}

Each raw milk sample was subjected to Storch test according to (lampert, 1975) as following: $10 \mathrm{ml}$ of milk samples, 2 drops of diluted ( $\mathrm{H}_{2} \mathrm{O} 2$ ) solution (one fraction of $\mathrm{H}_{2} \mathrm{O}_{2}, 14$ fractions of water and $0.1 \%$ of $\mathrm{H}_{2} \mathrm{SO}_{4}$ by volume) then add 2 drops of recently prepared watery solution of $2 \%$ paraphenylene-diamine were added. The contents were mixed thoroughly. Immediate appearance of indigo blue color indicated that the milk was raw.

\subsection{Qualitative detection of both antibiotics residues in verified raw milk samples using Screening Bacillus Subtilis Diffusion Assay}

Firstly, the antibiotic standard solution; which obtained by preparing different antibiotic concentrations from fortification solution in blank milk samples $(0.025,0.05,0.1,0.2,0.5,1.0$, 2.0 and $5 \mu \mathrm{g} / \mathrm{ml}$. Secondly, the Bacillus Subtilis spores suspension preparation (Arretet al., 1971) by sub-culturing the organism on both Nutrient agar slants and plates at $30^{\circ} \mathrm{C}$ for 24 hours (Oxoid Manual 1998) followed by collecting the growth using sterile saline to be centrifuged at $3000 \mathrm{rpm}$ for $10 \mathrm{~min}$. where the precipitate was suspended in $50 \mathrm{ml}$ of sterile saline and heated for $30 \mathrm{~min}$. at $70^{\circ} \mathrm{C}$. then this spore suspension was diluted with sterile saline to obtain density $10^{7}$ spores/ml by using Macfdian tube and the steps were proceeded as follows: One $\mathrm{ml}$ of the prepared spores suspension was added to $1000 \mathrm{ml}$ of Nutrient agar medium at $45-50^{\circ} \mathrm{C}$ to obtain a density $10^{4}$ spores $/ \mathrm{ml}$ then the medium was well mixed and poured into Petri dishes $(1 \mathrm{~cm}$ depth) in a quantity of $13 \mathrm{ml}$ then the plates were left at room temperature on a horizontal surface till complete solidification after which Sex pores were made on each plate using sterile borer with an outside diameter $(8.0 \mathrm{~mm})$ (Carter, 1988)followed by injecting $0.1 \mathrm{ml}$ of each concentration from the prepared antibiotic standard for both (OTC) \& (SMZ) antibiotics in the wells of each plate, while control and suspected raw milk samples were injected in the other wells. The plates were then incubated at $30^{\circ} \mathrm{C}$ for 24 hours and the width of prevention zones was recorded. Interpretation of the obtained results: Inhibition zone < $1 \mathrm{~mm}$ : negative; Inhibition zone 1-2 mm: suspected: Inhibition zone $>2 \mathrm{~mm}$ : positive.

2.4. Quantitative estimation of both antibiotics residues in suspected positive raw milk samples using HPLC

\subsubsection{HPLC equipment and conditions:}

(HPLC unite, chemistry department, Animal Health Research Institute, Dokki, Giza) Agilent series 1200 quaternary gradient pump, USA, An auto sampler plus surveyor, Agilent series 1200, USA, Multi wave detector, Agilent series 1200, USA, Chemstation software (Agilent- Germany) automatic analyser. Analytical column (stationary phase): the stationary phase was done on reversed phase Agilent C18 column (4.6 mm i.d., 250 $\mathrm{mm}, 5 \mu \mathrm{m})$. Surveyor, thermo scientific company, USA.

\subsubsection{Determination of (OTC) (Cinquinaet al., 2003)}

Five $\mathrm{ml}$ of suspected milk sample was moved into a polypropylene centrifuge tube with $t$ wo $\mathrm{ml}$ from $20 \%$ trichloroacetic acid (TCA) followed by mixing. $20 \mathrm{ml}$ of Mcllvaine buffer was added and the mix centrifuged at 4000 rpm for $20 \mathrm{~min}$. Then supernatant was administrated to a SPE HLB C18 cartridge; which earlier activated with $3 \mathrm{ml}$ of methanol and $2 \mathrm{ml}$ of $\mathrm{H} 2 \mathrm{O}$. After sample loading, the cartridge was cleaned with $2 \mathrm{ml}$ of methanol $5 \%$ in H2O. Finally (OTC) was removed with $3 \mathrm{ml}$ of methanol. Then this solvent was dried under a nitrogen stream then residues were soluble in 1 $\mathrm{ml}$ of methanol and filtrated with $0.45 \mu \mathrm{m}$ nylon syringe filter.

\subsubsection{Determination of (SMZ) (Weber and Smedley, 2001)}

In a separating funnel (125 $\mathrm{ml}$ capacity), ten $\mathrm{ml}$ of tested milk was transferred along with50 $\mathrm{ml}$ of chloroform and a stopper is placed. Then the mixture was vigorously mixed for 1 min; while an excess of pressure was carefully vented through stopper. The funnel was shaken again for $1 \mathrm{~min}$, vented, and the phases were separated for $1 \mathrm{~min}$. The previous step was repeated for another $1 \mathrm{~min}$. and the phases were separated for at least $5 \mathrm{~min}$. after separation, chloroform was drawn off and filtered through a fluted filter paper into a pear-shaped flask (100 $\mathrm{ml}$ capacity) then the filter paper was washed twice with $5 \mathrm{ml}$ portions from chloroform and the rinsing solution was received in the same pear-shaped flask. The chloroform solution exposed to evaporation process for dryness on a rotary evaporator at $32^{\circ} \mathrm{Cfollowed}$ by adding $5 \mathrm{ml}$ hexane to the flask and closure. The residues were dissolved by agitation vigorously on vortex mixer for $1 \mathrm{~min}$. with immediate addition 
of $1 \mathrm{ml} \mathrm{PDP} \mathrm{solution} \mathrm{the} \mathrm{vigorous} \mathrm{agitation} \mathrm{on} \mathrm{the} \mathrm{vortex} \mathrm{mixer}$ was repeated for about $1 \mathrm{~min}, 3$ to 4 times over a minimum of $15 \mathrm{~min}$. with subsequent discarding of any hexane. Finally, the aqueous layer from bottom of flask was transferred to an auto injector vial filtrated with $0.45 \mu \mathrm{m}$ nylon syringe filter.

\subsubsection{Heat treatment process (Boiling) (László et al., 2017)}

The samples of the raw milk that contain residues of antibiotic with a concentrations exceeded the permissible limit were heated at $100.17^{\circ} \mathrm{C}$ for different short periods. Heating (boiling) of milk samples were obtained using a stainless-steel pot. All Procedures were designed to stimulate the methods that used commonly in the household practices .The temperature of all heating processes was constantly measured by a thermometer at the exact time. Two sets of heat treatment were conducted. Firstly the samples were heated up to $100.17^{\circ} \mathrm{C}$ for 2 minutes, secondly milk samples were heated up to $100.17^{\circ} \mathrm{C}$ for 5 minutes. The time interval for boiling was measured from the actual boiling (bubbling) of the milk.

\section{RESULTS}

Upon applying the screening test, twenty-one (21) samples were positive (Inhibition zone $>2 \mathrm{~mm}$ ) and 4 samples were suspected (Inhibition zone 1-2mm). These 25 samples (12.5\%) were analysed for the existence of (OTC), (SMZ) residues using (HPLC)with a validation method to detect the quantity the two residues in raw milk and their results were illustrated in (table. 1). While the higher concentrations than permissible limit which heated at $100.17{ }^{\circ} \mathrm{C}$ for various short time-intervals (120 and 300 seconds) prevailing in household practice were illustrated in (table 2, 3,4and 5).

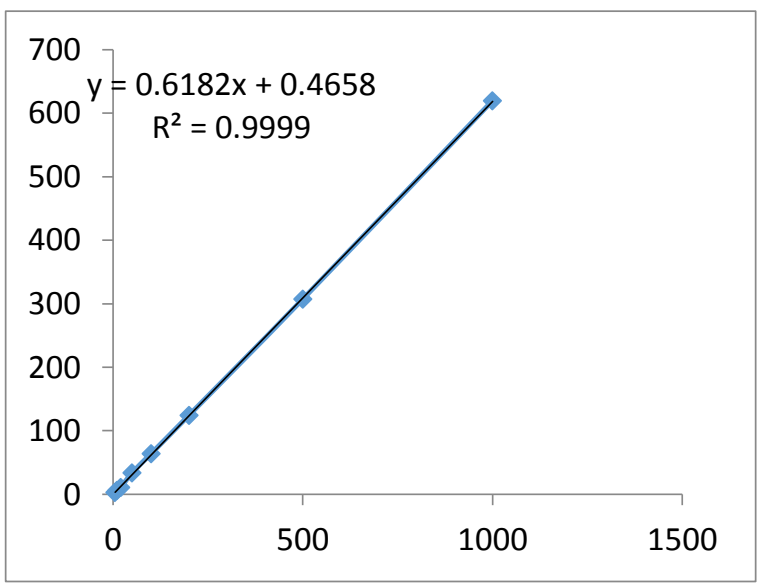

Figure 1. Standard curve of oxytetracycline

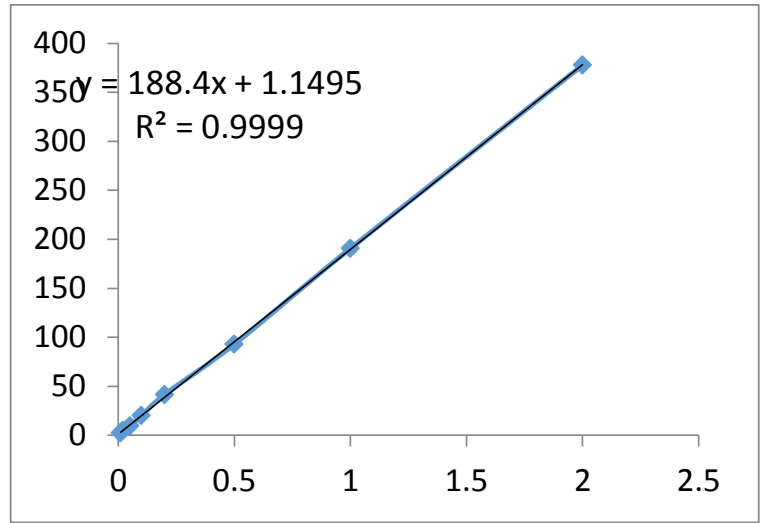

Figure 2. Standard curve of sulfamethazine

Table 1. Results of HPLC analysis for oxytetracycline and sulfamethazine residues.

\begin{tabular}{|ccc|}
\hline $\begin{array}{c}\text { Oxytetracycline residues } \\
(\mathrm{ng} / \mathrm{ml})\end{array}$ & $\begin{array}{c}\text { Sulfametharine residues } \\
(\mathrm{ng} / \mathrm{ml})\end{array}$ \\
\hline 1 & $100^{*}$ & 75 \\
2 & $146^{*}$ & $140^{*}$ \\
3 & $144^{*}$ & $152^{*}$ \\
4 & $100^{*}$ & 40 \\
5 & 92 & $102^{*}$ \\
6 & 50 & $142^{*}$ \\
7 & 62 & $116^{*}$ \\
8 & $122^{*}$ & $137^{*}$ \\
9 & $105^{*}$ & $\mathrm{Nd}$ \\
10 & $103^{*}$ & $\mathrm{Nd}$ \\
11 & $100^{*}$ & $\mathrm{Nd}$ \\
12 & $121^{*}$ & $\mathrm{Nd}$ \\
13 & $126^{*}$ & $\mathrm{Nd}$ \\
14 & $137^{*}$ & $\mathrm{Nd}$ \\
16 & $112^{*}$ & $\mathrm{Nd}$ \\
17 & $100^{*}$ & $\mathrm{Nd}$ \\
Mean & 119.6 & 131.5 \\
SE & 5.2 & 7.6 \\
\hline
\end{tabular}

$\left({ }^{*}\right)$ results $\geq$ MRL

Table 2. Oxytetracycline residues after boiling for 2 and $5 \mathrm{~min}$

$\begin{array}{cccc} & \begin{array}{c}\text { Before } \\ (\mathrm{ng} / \mathrm{ml})\end{array} & \begin{array}{c}\text { After boiling for }(\mathrm{ng} / \mathrm{ml}) \\ 120 \mathrm{sec} .\end{array} & \mathbf{3 0 0 \mathrm { sec }} \\ 1 & 100 & \mathrm{Nd} & \mathrm{Nd} \\ 2 & 146 & 106 & 66 \\ 3 & 144 & 100 & 63 \\ 4 & 100 & 75 & 45 \\ 5 & 122 & 91 & 51 \\ 6 & 105 & 74 & 44 \\ 7 & 103 & 74 & \mathrm{Nd} \\ 8 & 100 & 60 & \mathrm{Nd} \\ 9 & 121 & 89 & 52 \\ 10 & 126 & 94 & 56 \\ 11 & 137 & 98 & 51 \\ 12 & 112 & 48 & \mathrm{Nd} \\ 13 & 100 & 63 & \mathrm{Nd} \\ \text { Mean } & 116.6154 & 81^{* * *} & 53.5^{* * *} \\ \text { SE } & 4.811229 & 5.014664 & 2.17377\end{array}$


Table 3. Percentage reduction of Oxytetracycline before and after boiling process

\begin{tabular}{|c|c|c|c|}
\hline & Raw & $\begin{array}{c}\text { Boiling/ } 120 \\
\text { sec. }\end{array}$ & $\begin{array}{c}\text { Boiling/ } 300 \\
\text { sec. }\end{array}$ \\
\hline $\begin{array}{l}\text { Mean } \pm \text { SE } \\
\text { Percentage } 0\end{array}$ & $\begin{array}{l}116.6 \pm 4.8 \\
\text { ction }\end{array}$ & $81 \pm 5$ & $53.5 \pm 2.2$ \\
\hline & $100 \%$ & $30.5 \%$ & $54.1 \%$ \\
\hline
\end{tabular}

Table 4. Sulfamethazine residues after boiling for 2 and $5 \mathrm{~min}$

\begin{tabular}{llll}
\hline & \multicolumn{1}{c}{$\begin{array}{c}\text { Before } \\
(\mathrm{ng} / \mathrm{ml})\end{array}$} & \multicolumn{2}{c}{$\begin{array}{c}\text { After boiling for }(\mathbf{n g} / \mathrm{ml}) \\
\mathbf{1 2 0} \mathrm{sec} .\end{array}$} \\
\hline 1 & 140 & 137 & 130 \\
2 & 152 & 151 & 121 \\
3 & 102 & 102 & 100 \\
4 & 142 & 140 & 128 \\
5 & 116 & 114 & 110 \\
6 & 137 & 132 & 125 \\
Mean & 131.5 & 129.3333 & 119 \\
SE & 7.623429 & 7.374129 & 4.774935 \\
\hline
\end{tabular}

Table 5. Percentage reduction of Sulfamethazine before and after boiling process

\begin{tabular}{lccc}
\hline Raw & $\begin{array}{c}\text { Boiling/ 120 } \\
\text { sec. }\end{array}$ & $\begin{array}{c}\text { Boiling/ 300 } \\
\text { sec. }\end{array}$ \\
\hline $\begin{array}{c}\text { Mean } \pm \text { SE } \\
\text { 131.5 } \pm 7.6\end{array}$ & $129.3 \pm 7.4$ & $119 \pm 4.8$ \\
Percentage of reduction & & \\
$100 \%$ & $1.7 \%$ & $9.5 \%$ \\
\hline
\end{tabular}

\section{DISCUSSION}

Raw and natural food is increasing in popularity, as a part of modern-day dietary habits, raw milk and farmstead cheese are available directly from the producer, and many dairy products possible to be manufactured at home. However, the intake of these products may pose not only microbiological but also chemical adverse effect on the consumer's health. Moreover, milk and dairy products probably polluted with chemicals as, hygienic, agricultural, veterinary and environmental procedures (Claeyset al., 2013, Khaniki, 2007).

Veterinary drugs are utilized as a treatment or a prophylaxis for diseases in ediable producers such as betalactams and aminoglycosides which utilized in mastitis therapy (Botsoglou\&Fletouris 2001). The utilization of those products can't be avoided because of animal health points; despite, it can cause their existence in milk and other eaten tissues, in case of the withdrawal times are not noticed.

Antibacterial residues in milk can lead to in an important health concerns such as allergic symptoms (Dewdney et al., 1991), abnormalities in gut microflora, or affect the presence of resistant bacteria to antimicrobial medication (Mitchell et al., 1998). Also may result in adverse effects on starter cultures utilized to prepare dairy products at home or at industries in fermentation procedures (Tamime and Robinson, 2007).Maximum residue limits (MRLs) and withdrawal times are used to decrease and inhibit the risk and harmful effects of antibiotic residues in food of animal origin (FAO, 2015). Despite with the good notice to withdrawal times that not ensure that milk is residue-free. So the amount of residues might be below the MRLs. The varity of excretion rates between individuals lead tohigher concentrations not be discarded. Moreover, in case of utilization of milk in withdrawal period, results in residues above the permissible limit.

Before processing and consumption of raw milk, it under go heat treatment to decrease the presence of the zoonotic pathogens and to increase its validity period. Various thermal procedures are utilized in the dairy in manufacturing while raw milk is always exposed to boiling at home conditions (László et al., 2018). So, we studied the effect of boiling at $100.17^{\circ} \mathrm{C}$ on (OTC) and(SMZ)residues in raw milk samples.

At our investigation, two hundred raw milk samples (250 $\mathrm{ml}$ of each) were screened for qualitative determination of antibiotic residues using Bacillus Subtilis diffusion assay. Twenty-five samples (21 positive and 4 suspected) were examined for presence of (OTC) and (SMZ) residues using high performance liquid chromatography methods (quantitative determination) where the percentage of positive samples were $12.5 \%$, which slightly lower than those identified in Kenya(14\%) by both Shitandi and Sternesjo (2004) and Ekuttan et al. (2008).

Percent of (SMZ) in the examined milk samples slightly different in this study comparing with that of (OTC). A study by Ahlberget al. (2016)reported sulfonamides and tetracyclines in $0.4 \%$ and $2.5 \%$. While Mitemaet al. (2002) recorded sulfonamides and tetracyclines in $24 \%$ and $61 \%$ respectively.

In Germany, 2007 Kress and other co-authors found sulfonamides in $1.6 \%$ of milk samples, which is lower than that reported in Mexico 51.3\% (Tolentino et al.2005). Recent researches, the presence of tetracyclines, sulfonamides reported to be at limits higher than the permissible limits in milk at various sites of the value chain (Olatoyeet al., 2016; Chowdhury et al., 2015; Layadaet al.,2016) as $8.5 \%$ of the raw milk samples were containing (OTC) residues $(6.5 \%$ of them was exceed MRL) while $4 \%$ of the raw milk samples were containing (SMZ) residues (3\% of them was exceed MRL). Maximum residue limits for both antibiotics were $100 \mathrm{ng} / \mathrm{ml}$ according to EMEA, 2012.

In our study, boiling process for 2 and 5 minutes at 100.17 ${ }^{\circ} \mathrm{C}$ significantly reduced (OTC) residues where the reduction percentage was $(30.5 \%)$ and $(54.1 \%)$ respectively which can be attributed to the stability of (OTC) that agree with that 
have been mentioned by Kuhneet al., 2001 and Hassaniet al., 2008 who reported the thermal stability of (OTC), tetracycline and doxycycline in milk and found that conventional thermal procedures $\left(118^{\circ} \mathrm{C}, 30 \mathrm{~min}\right.$ or $\left.121^{\circ} \mathrm{C}, 20 \mathrm{~min}\right)$ could remove more than $98 \%$ of the residues.

These findings were agreed with that studied by László et al., 2017 who discussed the effect of boiling process of raw cow milk with the tetracyclines and sulfonamides and boiled for different short time-intervals common in home. LC-MS/MS measurements are used to determine antibiotic concentrations. Tetracyclines showed low stability in contrast to sulfonamides showed higher heat stability.

The influence of low temperature for long time of exposure (LTLT), pasteurization at $63^{\circ} \mathrm{Cfor}$ half an hour on CTC,TTC,OTC in raw milk was studied previously by Loksuwan (2002). The OTC residues in content of $100 \mu \mathrm{g} / \mathrm{l}$ inactivated to level of no detection, however at content of $200 \mu \mathrm{g} / \mathrm{l}$ and 300 $\mu \mathrm{g} / \mathrm{l}$ the initial OTC amount were noticed to be descend by $86.7 \%$ and $79.36 \%$, respectively. These results were much greater than our study because the heat treatment we chosed $\left(100.17^{\circ} \mathrm{C} / 2\right.$ and 5 minutes) was less effective in the removal of tetracycline residues. The temperature we used $\left(100.17^{\circ} \mathrm{C}\right)$ was higher, however it appears that the degradation of residues is affected by the heating period that shows the valuable variations in the values recorded in both studies. The two studies show that OTC in milk is more labile when exposed to thermal treatment. From all, our data confirm the published results, it found that boiling temperature because decrease in OTC residues in milk, but not cause a complete degradation of the antibiotic.

Hsieh et al. (2011) studied the effects of higher thermal treatments on thermal stability of tetracycline, double-distilled water used as a matrix. They used two different heating temperatures $\left(100{ }^{\circ} \mathrm{C}\right)$ and $121^{\circ} \mathrm{C}$ with time of exposure $(15$ min). Their findings show that higher temperatures $\left(121^{\circ} \mathrm{C} / 15\right.$ $\mathrm{min}$ ) cause tetracycline degradation of up to $99 \%$, while at 100 ${ }^{\circ} \mathrm{C}$ was $54.5 \%$. Beside that results, various degradation patterns showed by tetracyclines at $100.17^{\circ} \mathrm{C}$. The results of this study appear similarly as ours. Tetracyclines that have the same structure, and group can show variations in thermal stability. For this reason, the thermo-stability of antibiotics was unable to be predicted from their membership in a special group of medications.

Our results revealed that boiling process for 2 and 5 minutes slightly reduced sulfamethazine residues that were found in raw milk. The data revealed that the reduction in the SMZ content of milk boiled for 2 minutes was $1.7 \%$ while for 5 minutes it was $9.5 \%$. These results agree with Roca et al., 2010; who mentioned that sulfonamides have shown high heat stability during thermal treatments utilized in dairy manufacturing .beside that, different degrees of temperatures could not completely destroy antibiotics ( $722^{\circ} \mathrm{C}, 15 \mathrm{~s} ; 120^{\circ} \mathrm{C}, 20$ min; $140 \circ \mathrm{C}, 4 \mathrm{~s})$. Roca et al. 2013 indicated that sulfonamides were very stable during a process of pasteurization (63ㅇ, 30 $\min$ and $\left.72^{\circ} \mathrm{C}, 15 \mathrm{~s}\right)$ and UHT sterilization (140ㄷ, $\left.4 \mathrm{~s}\right)$. Sulfonamides were among the more heat-stable antibiotics and show variations in thermal stability from high-tointermediate degrees like each other (László et al., 2017).

\section{REFERENCES}

Ahlberg, S., Korhonen, H., Lindfors, E. and Kang'ethe, E. (2016): Analysis of antibiotic residues in milk from Smallholder farms in Kenya. African J Dairy Farmin Milk Prodc., 3(4):152-8.

Arret, B., Johnson, D. P. and Kirshbaum, A. (1971): Outline of details for microbiological assays of antibiotics: Second revision, journal of pharmaceutical sciences, 60(11): 1689-1694.

Botsoglou, N.A. and Fletouris, D.J. (2001):Drug Residues in Foods. Pharmacology, Food Safety and Analysis. New York: Marcel Dekker, Inc.94-101.

Brady, M.S. and Katz, S.E. (1988): Antibiotic/ antimicrobial residues in milk. Journal of Food Protection, 51: 8-11.

Carter, H. L., Wang, L. F., Doi, R. H. and Moran, C. P. (1988):rpoD operon promoter used by sigmaH-RNA polymerase in Bacillus Subtilis. J. Bacteriology.,170 (4):1617-1621.

Charm, S.E. and CHI, R. (1988): Microbial receptor assay for rapid detection and identification of seven families of antimicrobial drugs in milk: Collaborative study. J. Assoc. Off. Anal. Chem.,71:304-316.

Chowdhury, S., Hassan, M., Alam, M., Sattar, S., Bari, M.S., Saifuddin, A.K., Ahasanul, M.H. (2015): Antibiotic residues in milk and eggs of commercial and local farms at Chittagong, Bangladesh. Vet. World., 8(4):467-71.

Cinquina, A.L., Longo, F., Anastasi, G., Giannetti, L. and Cozzani, R. (2003): Validation of a high-performance liquid chromatography method for the determination of oxytetracycline, tetracycline, chlortetracycline and doxycycline in bovine milk and muscle. Journal of Chromatography A, 987: $227-233$

Claeys, W.L., Cardoen, S., Daube, G., De Block, J., Dewettinck, K., Dierick, K., De Zutter, L., Huyghebaert, A., Imberechts, H., Thiange, P., Vandenplas, Y. and Herman, L. (2013): Raw or heated cow milk consumption: Review of risks and benefits. Food Control., 31(1): 251-262.

Collins-Thompason, D.L., Wood, D.S. and Thomson, I.Q. (1988): Detection of Antibiotic Residues in consumer Milk Supplies in North America using the Charm Test II procedure. Journal of food protection, 51(8): 632-633.

Deeth, H.C. and Datta, N. (2003): Ultra-high temperature treatment (UHT): Heating systems. In: Roginski H (Ed Encyclopedia of Dairy Sciences. Academic Press, Amsterdam, pp. 2642- 2652

Dewdney, J.M., Maes, L., Raynaud, J.P., Blanc, F., Scheid, J.P., Jackson, T., Lens, S. \&Verschueren, C. (1991): Risk assessment of antibiotic residues of betalactams and macrolides in food products with regard to their immunoallergic potential. Food and Chemical Toxicology ., 29(7), 477-83.

EEC, (1992): Community procedure for the establishment of maximum residue limits of veterinary medicinial products in foodstuffs of animal origin. O.J.Eur.Com., L73: 8-14.

Ekuttan, C.E., Kang'ethe, E.K., Kimani, V.N. and Randolph, T.F. (2008) Investigation on the prevalence of antimicrobial residues in milk obtained from urban small holder dairy and non-dairy farming households in Dagoretti division, Nairobi, Kenya.EastAfr Med J.,84(11):87-91.

European Medicine Agency - EMEA (2012): Guideline on bioanalytical method validation. EMEA/CHMP/EWP/192217/2009.21 July 2011.

Food and Agriculture Organization of the United Nations \& World Health Organization, 2015: Codex Alimentarius Committee on Residues of Veterinary Drugs in Foods. http://www.fao.org/fao-whocodexalimentarius/standards/veterinary-drugs-mrls/en/ Accessed: 28.11.201.

Fritz, J.W. and Zuo, Y. (2007): Simultaneous determination of tetracycline, oxytetracycline and 4-epitetracycline in milk by high-performance liquid chromatography. Food Chemistry., 105 (3): 1297 - 1301. 
Hassani, M., Lázaro, R., Pérez, C., Condón, S. and Pagán, R. (2008): Thermostability of oxytetracycline, tetracycline, and doxycycline at ultrahigh temperatures. J Agr Food Chem., 56 (8): 2676-2680

Heeschen, W.H. (1993): Residues of antibiotics and sulfonamides in milk. Bulletin of the IDF No283/1993. International Dairy Federation, Brussel: 313.

Hsieh, M.K., Shyu, C.L., Liao, J.W., Franje, C.A., Huang, Y. J., Chang, S.K., Shih, P.Y., \& Chou, C.C. (2011): Correlation analysis of heat stability of veterinary antibiotics by structural degradation, changes in antimicrobial activity and genotoxicity. VeterinarniMedicina, 56 (6), 274-285.

Khaniki, G.R.J. (2007): Chemical contaminants in milk and public health concerns: A review. International Journal of Dairy Science, 2 (2), 104-115.

Kress, C., Seidler, C., Kerp, B., Schneider, E. and Usleber, E. (2007): Experiences with an identification and quantification program for inhibitor-positive milk samples. Anal Chim Acta.,586(1):275-9.

Kuhne, M., Korner, U. and Wenzel, S. (2001): Tetracycline residues in meat and bone meals. Part 2: the effect of heat treatments on bound tetracycline residues. Food Additives and Contaminants,18( 7):593-600.

Lampert, L.M. (1975): Modern Dairy Products 3rd ed., Chemical Publishing Company, Inc., New York USA.

László, N., Lányi, K. and Laczay, P. (2018): LC-MS study of the heat degradation of veterinary antibiotics in raw milk after boiling. Food Chemistry., (267):178-186.

Layada, S., Benouareth, D., Coucke, E. and Andjelkovic, M. (2016): Assessment of antibiotic residues in commercial and farm milk collected in the region of Guelma (Algeria). Int J Food Contam., 3:19.

Loksuwan, J. (2002): The effect of heating on Multiple Residues of Tetracyclines in milk. Thammasat Int.J.Sc.Tech.,7(3):17-21.

Mitchell, J.M., Griffiths M.W., Mc-ewen, S.A., Mc-nab, W.B. and Yee, A.J. (1998): Antimicrobial drug residues in milk and meat: cause, concerns, prevalence, regulations, tests, and test performance. Journal of Food protection., 61 (6): 742-756.

Mitema, E.S., Kikuvi, G.M., Wegener, H.C, Stohr, K. (2002): An assessment of antimicrobial consumption in food producing animals in Kenya. J Vet PharmacolTher., 24(6):385-90.

Moats, W.A. (1999): The effect of processing on veterinary residues in foods. Advances in Experimental Medicine and Biology,459: 233-241.

Nollet, M.L., ed. (1992):Food analysis by HPLC. New York: Marcel Dekker Inc.

Olatoye, I.O., Daniel, O.F. and Ishola, S.A. (2016): Screening of antibiotics and chemical analysis of penicillin residues in fresh milk and traditional dairy products in Oyo state, Nigeria. Vet. World., 9(9):948-54.

Oxoid Manual 8th Edition, 1998: pp. 2-208

Roca, M., Althaus, R.L., and Molina, M.P. (2013): Thermodynamic analysis of the thermal stability of sulphonamides in milk using liquid chromatography tandem mass spectrometry detection. Food Chemistry, 136:376-383.

Roca, M., Villegas, L., Kortabitarte, M.L., Althaus, R.L. and Molina, M.P. (2010): Effect of heat treatments on stability of $\beta$-lactams in milk. Journal of Agricultural and Food Chemistry,58:5427-5431.

Shitandi, A. and Sternesjo, A. (2004): Factors contributing to the occurrence of antimicrobial drug residues in Kenyan milk.J. Food Protection,67:339-402.

Tamime, A.Y. and Robinson, R. K. (2007): Tamime and Robinson's Yoghurt. Science and technology (3rd edition). Cambridge, UK: Woodhead Publishing Limited.

Tolentino, R.G., Perez, M.A., Gonzales, G.D., León, S.V. and López, M.G. (2005): Determination of the presence of 10 antimicrobial residues in Mexican pasteurized milk. Interciencia.., 30(5):291-4.

Weber, J.D. and Smedley, M.D. (2001): Rapid HPLC Determination of Sulfamethazine in Milk. Bacteriological Analytical Manual Chapter 20B.

WHO, (1989) : Evaluation of certin veterinary drug residues in food : Thirty fourth Report of the Joint FAO/WHO Expert Committee on Food Addatives. WHO Technical Report series World Health Organization, No.788, Geneva. 